\title{
PEMIDANAAN TERHADAP ANAK YANG BERHADAPAN DENGAN HUKUM
}

\author{
Muhammad Ridwan Lubis, Panca Sarjana Putra \\ Fakultas Hukum Universitas Muslim Nusantara, Medan \\ Fakultas Hukum Universitas Islam Sumatera Utara, Medan \\ muhammadridwanlubis76@gmail.com
}

\begin{abstract}
Abstrak
Tujuan penelitian ini adalah untuk menganalisis bagaimana perlindungan hukum terhadap anak yang berhadapan dengan hukum dan menjawa apa yang menjadi faktor utama anak konflik dengan hukum dan bagaimana peran penegak hukum dalam penanggulangan kasus-kasus terhadap anak yang berhadapan dengan hukum. Penelitian ini menggunakan penelitian hukum yuridis normatif. Tidak diragukan lagi, reintegrasi anak yang berhadapan dengan hukum adalah salah satunya hak-hak penting anak karena jika anak bertentangan dengan hukum tidak memiliki hak dan perawatan khusus sehingga tidak dapat berguna dalam masyarakat. Oleh karena itu, anak yang berkonflik dengan hukum membutuhkan perlindungan hukum dan dukungan masyarakat untuk melindungi mereka secara terpisah dari orang dewasa, karena mereka situasi, kapasitas fisik dan intelektual yang terbatas. Hasil penelitian menunjukkan faktor-faktor yang menjadi penyebab anak yang terlibat dalam kejahatan adalah keluarga faktor, faktor lingkungan /pertemanan, ekonomi, tingkat pendidikannya rendah dan alkohol/obat-obatan. Penyebabnya faktor yang harus dikurangi dan dihilangkan agar anak-anak tidak terlibat dalam melakukan kejahatan. Langkah-langkah atau upaya konkrit dari semua instansi pelaksana yang terkait dengan upaya penanganan anak yang berhadapan dengan hukum telah dilakukan namun belum menunjukkan hasil yang signifikan dalam memberikan dukungan terhadap perlindungan hak-hak anak
\end{abstract}

Kata kunci : Pemidanaan; Perlindungan Anak; Pidana Anak. 


\title{
CRIMINAL AGAINST CHILDREN AGAINST WITH LAW
}

\begin{abstract}
The purpose of this study is to analyze how legal protection is for children in conflict with the law and find out what are the main factors for children in conflict with the law and how the role of law enforcement is in dealing with cases against children in conflict with the law. This research uses normative juridical law research. Undoubtedly, the reintegration of children in conflict with the law is one of the important rights of children because if a child violates the law, he does not have special rights and treatment so he cannot be useful in society. Therefore, children in conflict with the law need legal protection and community support to protect them separately from adults, because of their situation, limited physical and intellectual capacities. The results of the study show that the factors that cause children to be involved in crime are family factors, environmental factors/friends, economics, low education levels and alcohol/drugs. The cause is a factor that must be reduced and eliminated so that children are not involved in committing crimes. Concrete steps or efforts from all implementing agencies related to efforts to handle children in conflict with the law have been carried out but have not shown significant results in providing support for the protection of children's rights. The cause is a factor that must be reduced and eliminated so that children are not involved in committing crimes. Concrete steps or efforts from all implementing agencies related to efforts to handle children in conflict with the law have been carried out but have not shown significant results in providing support for the protection of children's rights. The cause is a factor that must be reduced and eliminated so that children are not involved in committing crimes. Concrete steps or efforts from all implementing agencies related to efforts to handle children in conflict with the law have been carried out but have not shown significant results in providing support for the protection of children's rights.
\end{abstract}

Keywords: Criminalization; Child protection; Child Crime. 
e-ISSN : 2621-4105

\section{A. PENDAHULUAN}

Anak adalah generasi selanjutnya yang berpotensi untuk mengubah negara Indonesia menjadi negara yang lebih maju untuk itu anak sering juga disebut sebagai generasi penerus bangsa di hari mendatang yang berperan penting dalam menentukan sejarah bangsa dan negara serta hidup suatu bangsa di masa yang akan datang. Namun pada dasarnya perkembangan kejiwaan anak tidak sama dengan orang dewasa untuk itulah pendidikan sangat berperan sebagai pembentuk karakter anak. ${ }^{1}$

Istilah 'anak yang berkonflik dengan hukum' merujuk kepada siapa pun yang berusia di bawah 18 tahun yang melakukan kontak dengan sistem peradilan sebagai akibat dari dicurigai atau dituduh melakukan pelanggaran. Kebanyakan anak di konflik dengan hukum telah melakukan kejahatan kecil atau pelanggaran ringan seperti menggelandang, membolos, mengemis atau penggunaan alkohol. Beberapa di antaranya dikenal sebagai status pelanggaran dan tidak dianggap kriminal ketika dilakukan oleh orang dewasa. Selain itu, beberapa anak yang terlibat dalam perilaku kriminal telah digunakan atau dipaksa oleh orang dewasa. Terlalu sering, prasangka terkait dengan ras, etnis atau status sosial dan ekonomi mungkin membawa seorang anak ke dalam konflik dengan hukum bahkan ketika tidak ada kejahatan telah dilakukan, atau mengakibatkan perlakuan kasar oleh petugas penegak hukum.

Anak adalah "makhluk hidup yang memiliki keterbatasan dan kebutuhan perlindungan dari orang lain”. Pengertian anak dalam hukum pidana adalah "anak yang berhadapan dengan hukum yang selanjutnya disebut anak berumur 12 (dua belas) tahun, tetapi belum mencapai 18 (delapan belas) tahun tua yang diduga melakukan tindak pidana". Di United Anak-anak kerajaan berusia dari nol tahun sampai 18 tahun Dalam Amerika Serikat, yaitu New York dan Vermont, seseorang yang belum mencapai usia 16 masih disebut remaja. Ada perbedaan pemahaman anak masing-masing negara, karena perbedaan pengaruh sosial anak pembangunan, karena sosial budaya dan ekonomi aktivitas tiap negara berbeda. Meskipun banyak hal berpengaruh pada tingkat kematangan seorang anak. Itu menunjukkan bahwa pengaruh sosial, kegiatan sosial dan

${ }^{1}$ Ria Juliana, Ridwan Arifin, “Anak Dan Kejahatan (Faktor Penyebab Dan Perlindungan Hukum)”, Jurnal SELAT 6 (2), 2019, hal 225-234. DOI: https://doi.org/10.31629/selat.v6i2.1019 
e-ISSN : 2621-4105

budaya haruslah menjadi kepedulian pemerintah dan masyarakat untuk mencegah anak dari menjadi nakal.

Keadaan struktur sosial dan budaya di sekitarnya adalah penyebab kenakalan. Perkembangan struktur masyarakat dan keluarga sekitar seperti konflik orang tua menyebabkan kenakalan. Bahkan kenakalan terjadi karena aturan sosial yang tidak dapat dipenuhi oleh anak-anak sehingga mereka dianggap melanggar norma yang ditetapkan oleh suatu kelompok di komunitas sosial sekitarnya.

Komite Hak Anak telah meninjau semua laporan negara-negara di wilayah tersebut. Sambil menyambut perbaikan seperti baru hukum atau kode, pembentukan pengadilan atau pengadilan remaja, pendirian pusat rehabilitasi dan program pelatihan bagi aparat penegak hukum, komite memiliki menyatakan keprihatinan atas kurangnya kesesuaian antara undang-undang dan kebijakan dengan standar peradilan anak internasional. Telah berulang kali dicatat bahwa usia minimum tanggung jawab pidana terlalu rendah, bahwa perampasan kebebasan tidak digunakan hanya sebagai tolak ukur upaya terakhir, anakanak itu antara 16 dan 18 dianggap sebagai orang dewasa dan itu anak-anak di bawah 18 tahun, dalam banyak kasus, tidak terpisah dari orang dewasa saat berada di penahanan dan disimpan dalam kondisi yang sangat buruk dan tanpa akses ke dasar layanan. Panitia juga mengungkapkan kekhawatiran tentang laporan orang di bawah 18 tahun yang ditahan berdasarkan tindakan tertentu atau prosedur. ${ }^{2}$

Beberapa penelitian sebelumnya telah meneliti tentang pemidanaan terhadap anakanak. Hambali (2019) dalam penelitiannya yang berjudul "Penerapan Diversi terhadap Anak yang Berhadapan dengan Hukum dalam Sistem Peradilan Pidana”. Penelitian ini mengnalisis tentang bagaimaa penerapan diversi dalam restorative justice pada Sistem Peradilan Pidana Anak. Hasil penelitian menunjukkan bahwa penerapan diversi dalam keadilan restoratif pada sistem penerapan diversi terhadap anak yang berhadapan dengan hukum dalam sistem peradilan anak, merupakan implementasi sistem dalam keadilan restoratif untuk memberikan keadilan dan perlindungan hukum kepada anak yang berkonflik dengan hukum tanpa mengabaikan pertanggungjawaban pidana anak. Diversi bukanlah sebuah upaya damai antara anak yang berkonflik dengan hukum dengan korban

\footnotetext{
${ }^{2}$ IPU and UNICEF (2004) "Improving the Protection of Children in Conflict with the Law in South Asia A regional parliamentary guide on juvenile justice: A Handbook for Parliamentarians" (http:// www.ipu.org/english/handbks.htm\#child-prot) diakses tanggal 20 April 2021
} 
e-ISSN : 2621-4105

atau keluarganya akan tetapi sebuah bentuk pemidanaan terhadap anak yang berkonflik dengan hukum dengan cara nonformal. ${ }^{3}$

Sedangkan penelitian serupa oleh Nugroho (2017) dalam penelitiannya yang berjudul "Peran Balai Pemasyarakatan pada Sistem Peradilan Pidana Anak ditinjau Dalam Perspektif Hak Asasi Manusia”. Dalam penelitiannya tersebut Okky Chahyo mengindentifikasi perlindungan hak anak yang berkonflik dengan hukum dalam pembimbingan dan pendampingan yang dilakukan Balai Pemasyarakatan. Penelitian ini menyimpulkan bahwa perlindungan hak anak masih belum maksimal dalam sistem pembimbingan dan pendampingan oleh BAPAS, yaitu: masih ditemukan keterlambatan pembuatan litmas dan pendampingan oleh BAPAS, sehingga diperlukan penguatan kapasitas lembaga, karena peran BAPAS menjadi sangat penting di dalam perlindungan anak, sebagaimana yang telah diatur dalam Undang-Undang Sistem Peradilan Pidana Anak. $^{4}$

Terakhir penelitian dentang pemidanaan anak diangkat oleh Anjari (2021) dengan judul "Perlindungan Anak Yang Bermasalah Dengan Hukum Dalam Perspektif Pemidanaan Integratif Pancasila". Penelitian ini fokus menganalisisi kasus pemidanaan anak sesuai yang ada dalam Putusan Nomor 20/Pid.Sus-Anak/2015/PN.Pdg dan 01/Pid.Sus-An/2015/PN.Ngw. Dalam penelitiannya tersebut Warih Anjari fokus meneliti bagimana perlindungan terhadap pemidanaan anak menurut perspektif pemidanaan integratif berdasarkan Pancasila dalam dua putusan pemidanaan anak tersebut. ${ }^{5}$

Perbedaan penelitian ini dengan penelitian sebelumnya adalah bahwa penelitian ini lebih meneliti tidak hanya tentang perlindungan hukum terhadap anak yang berhadapan dengan hukum, tetapi juga faktor apa yang menjadi penyebab anak-anak menjadi pelanggar hukum. Tujuan penelitian ini adalah untuk menganalisis bagaimana perlindungan hukum terhadap anak yang berhadapan dengan hukum dan menjawa apa yang menjadi faktor utama anak konflik dengan hukum dan bagaimana peran penegak

\footnotetext{
${ }^{3}$ Azwad Rachmat Hambali, "Penerapan Diversi terhadap Anak yang Berhadapan dengan Hukum dalam Sistem Peradilan Pidana”. Jurnal Ilmiah Kebijakan Hukum 13 (1), 2019, hal 15-30. DOI: http://dx.doi.org/10.30641/kebijakan.2019.V13.15-30

${ }^{4}$ Okky Chahyo Nugroho, "Peran Balai Pemasyarakatan pada Sistem Peradilan Pidana Anak ditinjau Dalam Perspektif Hak Asasi Manusia” Jurnal HAM 8 (2), 2017, hal 161-174. DOI: http://dx.doi.org/10.30641/ham.2017.8.161-174

${ }^{5}$ Warih Anjari, "Perlindungan Anak Yang Bermasalah Dengan Hukum Dalam Perspektif Pemidanaan Integratif Pancasila”, Jurnal Jurnal Judisial 13 (3), 2021, hal 351-372. DOI: http://dx.doi.org/10.29123/jy.v13i3.435
} 
e-ISSN : 2621-4105

hukum dalam penanggulangan kasus-kasus terhadap anak yang berhadapan dengan hukum

\section{B. PERUMUSAN MASALAH}

Dalam penelitian ini permasalahan yang diangkat adalah :

1. Bagaimana perlindungan hukum terhadap anak yang berhadapan dengan hukum ?

2. Apa yang menjadi faktor utama anak konflik dengan hukum?

3. Bagaimana peran penegak hukum dalam penanggulangan kasus-kasus terhadap anak yang berhadapan dengan hokum?

\section{METODE PENELITIAN}

Jenis penelitian yang dilakukan dalam penyusunan artikel ini adalah ini penelitian hukum yuridis normatif, yaitu penelitian yang difokuskan untuk mengkaji penerapan kaedah-kaedah atau norma-norma hukum positif, dan yuridis empiris adalah penelitian yang dilakukan dengan meninjau masalah yang diteliti dari segi ilmu hukum dengan secara studi pustaka untuk memperoleh data sekunder yang diperlukan untuk menggali dan menganalisis mengenai Anak yang Berhadapan Dengan Hukum (ABH), sehingga pemahaman tentang $\mathrm{ABH}$ diantara para penegak hokum memiliki persepsi yang sama. Mengambil istilah Ronald Dworkin, penelitian semacam ini juga disebut dengan istilah penelitian doktrinal (doctrinal research), yaitu penelitian "yang menganalisa hukum baik tertulis di dalam buku (law at is written in the book), maupun hukum yang diputuskan oleh hakim melalui proses pengalihan (law as it decided by the jugle through judicial process)". 6

\section{HASIL DAN PEMBAHASAN}

\section{Perlindungan Hukum Terhadap Anak yang Berhadapan dengan Hukum}

Menurut Nicholas Mc Bala masa kanak-kanak adalah "masa perkembangan hidup, juga masa kemampuan terbatas untuk menyakiti orang lain". Status dan kondisi anak di Indonesia bersifat paradoks. Idealnya, anak adalah ahli waris dan pelopor masa depan bangsa. Secara riil, situasi anak-anak Indonesia masih dan terus memburuk. Itu dunia anak yang semestinya diwarnai dengan kegiatan bermain, mempelajari dan mengembangkan minat dan bakat mereka untuk masa depan, realitas diwarnai dengan data yang kelam dan menyedihkan. ${ }^{7}$ Anak-anak masih dan terus berurusan dengan

\footnotetext{
${ }^{6}$ Jhony Ibrahim, “Teori dan Metodologi Penelitian Hukum Normatif”, Surabaya: Bayumedia, 2008, hal. 282

7 Abu Huraerah, "Child Abuse (Kekerasan Terhadap Anak)", Edisi Revisi, Sptember 2007, NUANSA, Bandung, hal. 21
} 
e-ISSN : 2621-4105

hukum baik sebagai korban maupun sebagai pelaku. Kondisi ini membutuhkan perhatian khusus dari semua komponen masyarakat dan pemerintah untuk melindungi dan mengawasi tumbuh kembang anak Indonesia. Jadi anak-anak itu tidak dihadapkan pada hukum karena melakukan perbuatan menyimpang. Arah kebijakan hukum bertujuan untuk menjadikan hukum sebagai suatu peraturan yang mengatur memberikan perlindungan bagi hak-hak warga negara dan jaminan kehidupan masa depan di masa depan. $^{8}$

Menurut Anthony M. Platt ${ }^{9}$ definisi kenakalan adalah perbuatan anak yang meliputi (1) tindak pidana jika dilakukan keluar oleh orang dewasa (2) tindakan yang melanggar aturan negara atau masyarakat (3) perilaku tidak bermoral, membolos, kasar dan tidak senonoh kata-kata, tumbuh di jalanan dan pergaulan dengan orang jahat yang memungkinkan pengaruh buruk pada anak-anak di masa depan.

Perlindungan terhadap anak harus lebih diperhatikan lagi, karena melihat kenyaatan yang ada ternyata masih banyak kasus pelanggaran hak terhadap anak. Hal tersebut terlihat dari masih banyaknya kasus penelantaran anak, kasus penganiayaan anak, hingga kasus pembunuhan terhadap anak. Perlu ada ketegasan undang-undang dan kerjasama dari pemerintah serta masyarakat untuk bisa memberikan perlindungan terhadap amak, karena anak merupakan tanggung jawab kita semua sebagai manusia terlepas dari orang tua biologisnya. ${ }^{10}$

Negara bagian, pemerintah pusat, pemerintah daerah, keluarga dan orang tua atau wali berkewajiban dan bertanggung jawab atas implementasi perlindungan anak. Pemerintah negara bagian dan pemerintah daerah berkewajiban dan bertanggung jawab untuk menghormati pemenuhan hak anak tanpa memandang suku, agama, ras, kelas, jenis kelamin, etnis, budaya dan bahasa, status hukum, urutan kelahiran dan kondisi fisik dan/atau mental anak. Untuk memastikan pemenuhan hak-hak negara, itu adalah wajib memenuhi, melindungi dan menghormati hak-hak anak melalui kewajiban dan tanggung jawab Pemerintah dalam merumuskan dan melaksanakan kebijakan di bidang implementasi perlindungan anak. ${ }^{11}$

\footnotetext{
${ }^{8}$ Marlina, "Peradilan Pidana Anak Di Indonesia Pengembangan Konsep Diversi Dan Restorative Justice", Cetakan kedua, Refika Aditama, 2012, hal. 1

${ }^{9}$ Jack E Bynum dan William E Thompson, 2002, “Juvenile Delinquency A Sociological Approach”, Boston : A Peason Education Company, Allyn and Bacon, Fifth edition, hal. 9

${ }^{10}$ Nopiana Mozin, Maisara Sunge, "Pemberian Edukasi Dan Bantuan Hukum Terhadap Anak Korban Kekerasan”, Jurnal Ius Constituendum 6 (1), 2021, hal 166-181. DOI : 10.26623/jic.v6i1.2485

${ }^{11}$ Barda Nawawi Arif, "Bunga Rampai Kebijakan hukum Pidana", Bandung, Citra Aditya Bakthi, hal 35
} 
e-ISSN : 2621-4105

Perlindungan hukum anak adalah "perlindungan yang menjamin hak dan kewajiban anak”. Bentuk hukum perlindungan anak hukum adat, hukum perdata, hukum pidana, acara pidana hukum, peraturan lain tentang anak. Perlindungan anak, menyangkut berbagai aspek kehidupan dan penghidupan, sehingga anak benar-benar dapat tumbuh dan berkembang sesuai dengan alam dengan hak asasi manusia mereka. ${ }^{12}$

Menurut Bismar Siregar itu masalah proteksi bagi anak-anak merupakan salah satu sisi pendekatan untuk melindungi Indonesia anak-anak. Masalahnya bukan hanya bisa mendekat secara yuridis, tetapi juga membutuhkan pendekatan yang lebih luas, yaitu ekonomi, sosial dan budaya. ${ }^{13}$

Banyak anak menghadapi persidangan bahkan ketika mereka di bawah usia kriminal tanggung jawab karena mereka tidak dapat membuktikan usia mereka. Dalam praktiknya, menentukan usia anak yang ditangkap mungkin bermasalah. Seringkali sulit untuk menemukan kelahiran registrasi resminya. Anak yang kelahirannya belum terdaftar atau yang belum pernah bersekolah tidak memiliki catatan usia yang sah. Polisi dilaporkan juga gagal mencatat usia anak atau dengan sengaja mencatat peningkatan usia untuk menghindari keharusan mematuhi perlindungan prosedural. Anak-anak yang melakukan tindakan ilegal tetapi terlalu muda untuk dimintai pertanggungjawaban, undang-undang tentang pelaku remaja mungkin ditangani dengan prosedur lain kebanyakan dalam pendekatan kesejahteraan. Anak bisa ditempatkan di sebuah lembaga kesejahteraan alasan tanpa pengadilan dan tidak memiliki kemungkinan peninjauan kembali atau banding, yang artinya bahwa sistem pemantauan independen harus menindaklanjuti dan meninjau kesejahteraan ini kasus

Anak-anak yang kurang dewasa dan kurang bersalah memiliki potensi rehabilitasi yang lebih besar daripada orang dewasa. Studi menunjukkan bahwa pendekatan hukuman dan pencegahan memiliki efek terbatas pada anak-anak karena mereka tidak memiliki kapasitas untuk memahami konsekuensi dari tindakan mereka dan mengontrol impuls mereka. Apalagi melihat kerentanan karena usia mereka, penahanan menempatkan mereka berisiko mengalami kekerasan dan pelecehan seksual dan mengekspos anak pada kontaminasi kriminal dari sesama narapidana dan stigma, yang memiliki efek negatif

\footnotetext{
${ }^{12}$ Irma Setyowati Sumitro, “Aspek Hukum Perlindungan Anak”, Bumi Aksara, Jakarta, 1990, hal 15.

${ }^{13}$ Bismar Siregar dkk, "Hukum dan Hak-Hak Anak", Rajawali, 1986, hal. 22
} 
e-ISSN : 2621-4105

jangka panjang pada masa depan anak. Hak-hak anak dijamin melalui Konvensi Perserikatan Bangsa-Bangsa tentang Hak Anak dan perjanjian, pedoman dan standar lain yang relevan. Menurut hukum internasional, yang utama tujuan intervensi yang berkaitan dengan pidana anak haruslah direhabilitasi dan direintegrasi anak, daripada hukuman. Jika memungkinkan, perlu dialihkan dari pengadilan formal sistem, menjadi hukuman alternatif harus diterapkan, dan penahanan harus menjadi ukuran terakhir resor untuk jangka waktu yang paling singkat. Sebagai aturan umum, anak-anak tidak boleh menjadi sasaran perampasan kebebasan kecuali mereka melakukan kejahatan yang sangat serius yang melibatkan kekerasan, atau terus berlanjut melakukan kejahatan yang sangat serius lainnya, dan tidak ada tanggapan lain yang sesuai.

Khusus pertimbangan harus diberikan pada kekhususan gender. Ada kebutuhan untuk memprioritaskan penerapan tindakan non-penahanan untuk gadis-gadis yang telah bertentangan dengan hukum dan untuk memberikan yang khusus perlindungan bagi tahanan perempuan. Berdasarkan kerangka hukum internasional, perlu dilakukan modifikasi terhadap keadilan standar sistem untuk menanganinya: membuatnya ramah anak, memastikan partisipasi penuh dan efektif dari anak-anak, dorong rehabilitasi dan pastikan privasi remaja dan hindari stigmatisasi.

\section{Alasan Utama Anak Konflik dengan Hukum}

Teknologi yang semakin modern selain menunjukkan keunggulannya dan memberikan kemudahan untuk manusia, disisi lain juga teknologi mempunyai pengaruh negatif yang sangat besar untuk kalangan masyarakat terutama para remaja yang akan meranjak dewasa yang masih mencari jati dirinya untuk menjadi diri sendiri. Pengaruh negatif ini memberikan dampak yang sangat besar untuk para remaja sehingga menyebabkan banyaknya kejahatan yang sering dilakukan oleh anak remaja yang masih duduk dibangku SMP dan SMA. Akibat rasa ingin tahu tanpa didampingi dan bimbingan yang positif dari orang tua sehingga mereka (anak-anak remaja) mencari tahu dengan jalan yang tidak sesuai dengan kaidah Islam maupun aturan hukum yang berlaku. ${ }^{14}$

Alasan yang menimbulkan konflik antara anak dan hukum sangat beragam dan kompleks. Mereka mencakup kemiskinan, kehancuran keluarga, keluarga orang tua

${ }^{14}$ Mega Widyawati, “Tindak Pidana Persetubuhan Pada Anak Ditinjau Dari Hukum Positif Dan Hukum Islam”, Jurnal USM Law Review 1 (1), 2018, hal 68-81. DOI : 10.26623/julr.v1i1.2232 
e-ISSN : 2621-4105

tunggal, keluarga yang direkonstruksi, tekanan teman sebaya, kurangnya pendidikan, pengangguran, atau tidak adanya perspektif kejuruan, panduan yang salah orang tua, mengabaikan. Banyak anak yang berkonflik dengan hukum menjadi korban kesulitan sosial ekonomi. Ini merampas mereka hak atas pendidikan, kesehatan, tempat tinggal, perawatan dan perlindungan. Banyak anak tidak mengenyam pendidikan atau hanya hadir beberapa tahun, banyak dari mereka harus mulai bekerja pada usia dini

Sebagian dari anak-anak ini melarikan diri dari rumah, lebih memilih jalan-jalan daripada kekerasan dalam rumah tangga. Yang lainnya dipaksa turun ke jalan dan menjadikannya tempat tinggal mereka, dengan harapan bisa bertahan hidup. Anak-anak terlantar, terlantar atau dilanda kemiskinan menjadi sasaran organisasi kriminal, yang mengekspos mereka pada eksploitasi seksual, perdagangan anak, dan keterlibatan dalam perdagangan narkoba.

Intervensi global, sosial dan ekonomi diperlukan untuk menghilangkan akar penyebab tersebut: termasuk program memerangi kemiskinan, pendidikan, kejuruan, dan program konseling orang tua. Sejalan dengan itu, sangatlah penting untuk menjangkau anak-anak yang sudah berada dalam sistem peradilan, untuk menghalangi mereka mengejar karir kriminal mereka, dan mendukung rehabilitasi dan inklusi mereka (kembali) ke dalam masyarakat. ${ }^{15}$

Masa kanak-kanak merupakan masa yang sangat rentan untuk dilakukan tindakan, anak-anak sangat rentan dengan berbagai keinginan dan harapan yang ingin dicapai sesuatu dan lakukan sesuatu. Seorang anak dalam melakukan sesuatu melakukannya tidak/kurang menilai konsekuensi dari tindakannya.

Kebutuhan ini tidak semuanya dapat dipenuhi oleh seorang anak sendiri tetapi kebutuhan bantuan dari orang dewasa. Orang tua/dewasa memiliki kewajiban untuk membantu anak-anak secara fisik, ekonomi dan psikologis di perkembangan mental anak. Anak-anak tidak dapat memenuhi kebutuhan ini, anak-anak terhambat perkembangannya dan bahkan bisa menyebabkan gangguan mental, akhirnya menjadi kenakalan aktor. Menurut Richard Dembo, dkk. anak-anak yang mengalami banyak kesulitan seperti kesulitan dalam membiasakan diri dalam keluarga, menjadi secara ekonomi orang-orang

\footnotetext{
${ }^{15}$ United Nations Office on Drugs and Crime, “Criminal Justice Assessment Toolkit”, New York, 2007, Part III Alternatives to Incarceration, p. 12
} 
e-ISSN : 2621-4105

yang depresi atau ekonomi rendah memiliki risiko lebih tinggi untuk menjadi pelaku kenakalan dari pada anak yang menderita fisik dan perampasan seksual.

Berdasarkan hasil penelitian tahun 2018 menunjukkan bahwa faktor-faktor tersebut Penyebab anak melakukan kenakalan adalah: pengaruh hubungan/teman sebaya, kurangnya perhatian dari orang tua dan keluarga, rumah rusak (keluarga berantakan), ekonomi (pendidikan). Faktor langsung atau tidak penting kecerdasan anak. Ini faktor ada sejak lahir seperti kecerdasan. oleh karena itu demikian diperlukan peningkatan kualitas kecerdasan pada anak. Anak yang kurang cerdas akan mengalami kesulitan mengendalikan emosi dan keinginannya, sehingga mudah jatuh menjadi kejahatan, bahkan jika mereka tidak bertanggung jawab secara langsung kejahatan. Diversi bertujuan untuk meniadakan aspek hukuman yang didapat jika seseorang melakukan tindak pidana, namun di lain pihak, hilangnya aspek hukuman tersebut tidak serta merta meniadakan sangsi yang diterima oleh pelaku tindak pidana. Dalam hal ini pelaku tetap mendapatkan sangsi namun sangsi tersebut bukan merupakan suatu hukuman melainkan suatubentuk tanggungjawab yang harus dilakukan karena telah melakukan kesalahan (tindak pidana). ${ }^{16}$

Sistem restorative justice telah diutamakan dalam hukum pidanadaengan mencoba untuk mengintegrasikan tiga kepala segitiga: pelaku - korban - masyarakat. Model ini didasarkan pada gagasan bahwa perlindungan sistem tidak cukup terfokus pada pelanggaran, dan tidak cukup mementingkan gagasan mengubah anak di bawah umur menjadi makhluk yang bertanggung jawab. Model tersebut memperkenalkan kembali korban di pengadilan peradilan anak. Seluruh intervensi dengan demikian berorientasi pada penyadaran pemuda kerugian yang ditimbulkan oleh perbuatan itu. Ini juga menumbuhkan kesadaran akan perlunya menebus kerusakan, dan untuk mengambil sikap yang jelas terhadap nilai yang ingin dibagikan oleh komunitas. ${ }^{17}$

\section{Peran Penegak Hukum dalam Penanggulangan Kasus-Kasus Terhadap Anak Yang Berhadapan Dengan Hukum}

Sebagai generasi penerus, anak-anak haruslah menjadi individu yang dapat dipersiapkan dengan matang untuk masa depannya, namun seiring perubahan

\footnotetext{
${ }^{16}$ Lilien Ristina, "Peran Jaksa Dalam Penerapan Kebijakan Diversiterhadap Anak Pelaku Tindak Pidana", Jurnal Ius Constituendum 3 (2), 2018, hal. 166-178. DOI : 10.26623/jic.v3i2.1038

${ }^{17}$ Cahyasena Putu Yudha, , "Tinjauan Kriminologi Terhadap Anak yang Berkonflik Dengan Hukum (Study Kasus di Bapas Kelas II Mataram)”, Jurnal Kerthawicara 5 (3), 2016.
} 
jaman, dan perubahan sosial memiliki dampak yang sungguh uar biasa dalam perubahan yang terjadi permasalahan anak berupa penelantaran, eksploitasi, perdagangan anak, diskriminasi, kekerasan terhadap anak baik fisik, psikis dan seksual. Kebutuhan tentang perlindungan anak sangat dibutuhkan agar kondis anak dapat bertahan dalam dunia yang semakin keras. ${ }^{18}$

Penanganan terhadap anak yang berhadapan dengan hukum adalah bagian dari kebijakan atau upaya penanggulangan kejahatan karena tujuan utamanya adalah perlindungan anak dan mensejahterakan anak dimana anak merupakan bagian dari masyarakat. Kebijakan atau upaya penanggulangan pada hakekatnya merupakan bagian integral dari upaya perlindungan masyarakat (social defence) dan upaya mencapai kesejahteraan masyarakat (social welfare). ${ }^{19}$ Pendat dari G. Pieter Hoefnagels mengatakan, keterlibatan masyarakat dalam kebijakan penanggulangan kejahatan (criminal policy) sangat penting, karena kebijakan penanggulangan merupakan usaha rasional dari masyarakat sebagai reaksi terhadap kejahatan. ${ }^{20}$ Upaya penanggulangan terhadap anak yang berhadapan dengan hukum dilakukan dengan cara terpadu yang mencangkup 3 (tiga) tindakan yaitu tindakan preventif, tindakan penghukuman, dan tindakan kuratif.

Penjatuhan pidana terkhusus pidana penjara yang diberikan oleh hakim terhadap anak mengakibatkan jatuhnya hukuman terhadap anak yang melakukan perbuatan melawan hukum maka dengan itu pertimbangan dari petugas kemasyarakatan baik dari pembimbing kemasyarakatan itu sendiri ataupun dari Departemen Kehakiman, petugas dari kemasyarakatan dan Departemen Sosial serta petugas sukarela dari organisasi sosial kemasyarakatan tersebut. $^{21}$

Sesuai dengan Konvensi Hak Anak yang telah di ratifikasi oleh indonesia melalui Keputusan Presiden No. 36 Tahun 1990, maka seyogyanya Indonesia telah berkomitmen dalam upaya perlindungan hak anak secara keseluruhan. Disamping itu, Indonesia juga telah mempunyai Undang-Undang Nomor 23 Tahun 2002 tentang Perlindungan Anak

\footnotetext{
${ }^{18}$ Tateki Tursilani, "Dampak Kekerasan Seksual di Ranah Domestik Terhadap Keberlangsungan Hidup Anak”, Jurnal Media Informasi Penelitian Kesejahteraan Sosial 41 (1), 2017.

${ }^{19}$ Nawawi, Barda Arief, 2012, "Bunga Rampai Kebijakan Hukum Pidana", PT Citra Aditya Bakti, Bandung, hal 2.

${ }^{20}$ Marlina, 2009, "Peradilan Pidana Anak di Indonesia, Pengembangan Konsep Diversi dan Restoratif Justice, Refika Aditama, Bandung”, hal.15.

${ }^{21}$ Bambang Purnomo, Gunarto, "Penegakan Hukum Tindak Pidana Anak Sebagai Pelaku Dalam Sistem Peradilan Pidana Anak (Studi Kasus di Polres Tegal)”, Jurnal Hukum Khaira Ummah 13 (1) 2018, hal 46.
} 
e-ISSN : 2621-4105

sebagai satu upaya dalam memberikan upaya perlindungan terhadap hak-hak anak seperti di bidang pendidikan, kesehatan, agama, dan sosial termasuk hak anak yang berhadapan dengan hukum. Anak yang berhadapan dengan hukum termasuk dalam kriteria yang diberikan Perlindungan Khusus seperti yang di nyatakan dalam Pasal 59 Undang-Undang Nomor 23 Tahun 2002. Hal ini merupakan tanggung jawab pemerintah dan masyarakat. Pasal 64 Undang-Undang Nomor 23 Tahun 2002 menyatakan lebih lanjut bahwa perlindungan anak yang berhadapan dengan hukum meliputi anak yang berkonflik dengan hukum dan anak korban tindak pidana. Terkait dengan permasalahan anak yang berhadapan dengan hukum $(\mathrm{ABH})$ masih menunjukkan situasi dan kondisi yang masih memprihatinkan salah satu contohnya dikarenakan terbatasnya rumah tahanan dan Lapas Anak, maka tidak semua daerah memiliki Lapas Anak, sehingga masih terjadi penyatuan antara tahanan anak dengan orang dewasa.

Menurut standar internasional, sistem peradilan anak harus bertujuan untuk mendorong spesialisasi dalam praktik peradilan anak dan mengembangkan sistem pidana yang berbeda keadilan yang memperlakukan anak dengan cara yang sesuai dengan usia dan tingkat kedewasaan mereka. Sebagian besar negara di kawasan ini memiliki prosedur peraturan perundang-undangan yang terpisah untuk anak-anak yang berkonflik dengan hukum. Ia mengakui perlunya perlakuan khusus terhadap anak-anak dan memasukkan aspek fundamental dasar dari peradilan anak, seperti pemisahan anak-anak dari orang dewasa, pembentukan pengadilan remaja, kebutuhan akan rehabilitasi dan larangan perlakuan kasar dan kejam. Namun, ini ketentuan-ketentuan seringkali tidak sepenuhnya sesuai dengan instrumen internasional dan memang hampir tidak diterapkan dalam praktik. Banyak konsep undang-undang keadilan 'modern' - jelas pemisahan antara pelaku anak dan anak yang membutuhkan perlindungan, pengalihan dan keadilan restoratif, preferensi untuk rehabilitasi berbasis komunitas dan komunitas keterlibatan tidak diterapkan. Belum ada negara di wilayah tersebut yang telah sepenuhnya menerapkan remaja yang terpisah dan berbeda sistem peradilan untuk memastikan bahwa anak-anak yang berkonflik dengan hukum diperlakukan dengan cara jauh berbeda dari orang dewasa. Namun, ada dorongan yang signifikan untuk reformasi dalam beberapa tahun terakhir seperti yang terlihat dalam komitmen pemerintah Bhutan, Maladewa, Nepal dan Sri Lanka. 
e-ISSN : 2621-4105

Anak-anak yang berkonflik dengan hukum, termasuk residivis anak, berhak diperlakukan dengan cara yang mempromosikan reintegrasi mereka dan anak yang mengambil peran konstruktif dalam masyarakat. Dalam pendapat komite, kewajiban negara-negara pihak untuk mempromosikan langkah-langkah penanganan anak-anak yang berkonflik dengan hukum tanpa menggunakan proses peradilan berlaku, tetapi tentu saja tidak terbatas pada anak-anak yang melakukan pelanggaran ringan, seperti mengutil atau pelanggaran properti lainnya

Langkah-langkah atau upaya konkrit dari semua instansi pelaksana yang terkait dengan upaya penanganan anak yang berhadapan dengan hukum telah dilakukan namun belum menunjukkan hasil yang signifikan dalam memberikan dukungan terhadap perlindungan hak-hak anak dalam situasi pemenjaraan. Anak yang mengalami perkara dengan hukum, dalam proses peradilan masih diperlukan dan diproses dalam peraturan perundang-undangan yang pada saat ini berlaku dan belum menerapkan konsep diversi and restrorative justice (keadilan restoratif) yaitu secara garis besar memberikan upaya perlindungan untuk terbaik anak.

\section{E. PENUTUP}

Hasil penelitian menunjukkan faktor-faktor yang menjadi penyebab anak yang terlibat dalam kejahatan adalah keluarga faktor, faktor lingkungan/pertemanan, ekonomi, tingkat pendidikannya rendah dan alkohol/obat-obatan. Penyebabnya faktor yang harus dikurangi dan dihilangkan agar anak-anak tidak terlibat dalam melakukan kejahatan. Lebih lanjut lagi perlindungan dari negara dan perhatian orang tua, orang dewasa dan lingkungan di masyarakat sangat membantu anak-anak untuk kembali menjadi anak-anak sesuai dengan kondisi dan pengembangan. Masa kanak-kanak merupakan masa yang sangat rentan untuk dilakukan tindakan, anak-anak sangat rentan dengan berbagai keinginan dan harapan yang ingin dicapai sesuatu dan lakukan sesuatu. Seorang anak dalam melakukan sesuatu melakukannya tidak / kurang menilai konsekuensi dari tindakannya. Kebutuhan ini tidak semuanya dapat dipenuhi oleh seorang anak sendiri tetapi kebutuhan bantuan dari orang dewasa. Orang tua / dewasa memiliki kewajiban untuk membantu anak-anak secara fisik, ekonomi dan psikologis di perkembangan mental anak. Anak-anak tidak dapat memenuhi kebutuhan ini, anak-anak terhambat perkembangannya dan bahkan bisa menyebabkan gangguan mental, akhirnya menjadi 
e-ISSN : 2621-4105

kenakalan pelaku. Penanggulangan dan penanganan anak yang berhadapan dengan hukum bertujuan untuk merubah perilaku dan sikap anak yang menyimpang, serta memberikan dorongan agar anak yang tersebut dapat diterima kembali dalam lingkungan masyarakat. Langkah-langkah atau upaya konkrit dari semua instansi pelaksana yang terkait dengan upaya penanganan anak yang berhadapan dengan hukum telah dilakukan namun belum menunjukkan hasil yang signifikan dalam memberikan dukungan terhadap perlindungan hak-hak anak

\section{DAFTAR PUSTAKA}

Buku

Abu Huraerah, "Child Abuse (Kekerasan Terhadap Anak)", Edisi Revisi, NUANSA, Bandung, 2007.

Barda Nawawi Arif, “Bunga Rampai Kebijakan Hukum Pidana”, Bandung, Citra Aditya Bakti.

Bismar Siregar dkk, "Hukum dan Hak-Hak Anak”, Rajawali, 1986

Irma Setyowati Sumitro, “Aspek Hukum Perlindungan Anak”, Bumi Aksara, Jakarta, 1990.

Maidin Gultom, "Perlindungan Hukum Terhadap Anak Dengan Sistem Peradilan Pidana Anak di Indonesia", cetakan Ke empat Revisi, Refika Aditama.

Marlina, "Peradilan Pidana Anak di Indonesia, Pengembangan Konsep Diversi dan Restoratif Justice", Refika Aditama, Bandung, 2009.

, "Peradilan Pidana Anak Di Indonesia Pengembangan Konsep Diversi Dan Restorative Justice", Cetakan kedua, Refika Aditama, 2012.

Nawawi, Barda Arief, 2012, “Bunga Rampai Kebijakan Hukum Pidana”, PT Citra Aditya Bakti, Bandung.

United Nations, "Office on Drugs and Crime, Criminal Justice Assessment Toolkit", New York, 2007, Part III Alternatives to Incarceration.

\section{Jurnal}

Azwad Rachmat Hambali, "Penerapan Diversi terhadap Anak Yang Berhadapan dengan Hukum dalam Sistem Peradilan Pidana”. Jurnal Ilmiah Kebijakan Hukum 13 (1), 2019.

DOI: http://dx.doi.org/10.30641/kebijakan.2019.V13.15-30

Lilien Ristina, "Peran Jaksa Dalam Penerapan Kebijakan Diversiterhadap Anak Pelaku Tindak Pidana", Jurnal Ius Constituendum 3 (2), 2018. DOI : 10.26623/jic.v3i2.1038

Mega Widyawati, "Tindak Pidana Persetubuhan Pada Anak Ditinjau Dari Hukum Positif Dan Hukum Islam", Jurnal USM Law Review 1 (1), 2018. DOI $: \underline{10.26623 / j u l r . v 1 i 1.2232}$

Nopiana Mozin, Maisara Sunge, "Pemberian Edukasi Dan Bantuan Hukum Terhadap Anak Korban Kekerasan”, Jurnal Ius Constituendum 6 (1), 2021. 
e-ISSN : 2621-4105

DOI : $10.26623 /$ jic.v6i1.2485

Cahyasena Putu Yudha, 2016, "Tinjauan Kriminologi Terhadap Anak yang Berkonflik Dengan Hukum (Study Kasus di Bapas Kelas II Mataram)", Jurnal Universitas Udayana, Denpasar,

Okky Chahyo Nugroho, "Peran Balai Pemasyarakatan pada Sistem Peradilan Pidana Anak ditinjau Dalam Perspektif Hak Asasi Manusia” Jurnal HAM 8 (2), 2017.

DOI: http://dx.doi.org/10.30641/ham.2017.8.161-174

Tateki Tursilani, "Dampak Kekerasan Seksual di Ranah Domestik Terhadap Keberlangsungan Hidup Anak", Jurnal Media Informasi Penelitian Kesejahteraan Sosial 41 (1), 2017.

Ria Juliana, Ridwan Arifin, "Anak Dan Kejahatan (Faktor Penyebab Dan Perlindungan Hukum)", Jurnal SELAT 6 (2), 2019, hal 225-234. DOI: https://doi.org/10.31629/selat.v6i2.1019

Warih Anjari, "Perlindungan Anak Yang Bermasalah Dengan Hukum Dalam Perspektif Pemidanaan Integratif Pancasila”, Jurnal Jurnal Judisial 13 (3), 2021.

DOI: http://dx.doi.org/10.29123/jy.v13i3.435

\section{Artikel}

Purnianti, "Garis Besar Analisa Situasi Sistem Peradilan Pidana Anak Di Indonesia”, Seminar Sehari Peradilan Anak Mengembangkan Diversi Dan Restorative Justice, 2003. Jakarta.

\section{Internet}

IPU and UNICEF (2004) "Improving the Protection of Children in Conflict with the Law in South Asia A regional parliamentary guide on juvenile justice: A Handbook for Parliamentarians" (http:// www.ipu.org/english/handbks.htm\#childprot) 